\title{
Foucauldian Biopolitics, Irregular Immigrants and COVID-19 in Malaysia
}

\author{
Omer Faruk Cingir ${ }^{\mathrm{a}}$ and Thirunaukarasu Subramaniam ${ }^{\mathrm{b}}$
}

\begin{abstract}
This paper addresses issues related to irregular immigrants during the COVID-19 pandemic, with the aim of providing a better understanding of the migration process in Malaysia. This article uses Foucauldian biopolitics as a theoretical framework to explain state practices on immigrant bodies. Firstly, it provides a general picture of irregular immigration in Southeast Asia and Malaysia; secondly, it summarises the effects of the pandemic; and lastly it provides an overall outlook of irregular immigrants and the practices they were exposed to at this time. This study adopts exploratory and explanatory qualitative research design and data collection techniques such as document analysis of non-governmental reports on immigrants, official statistics, declarations and articles produced by third party organisations and interviews with experts. This paper then adopts a post-structuralist perspective within an interpretative paradigm to comprehend the main problems, social arrangements and rationality of institutional dynamics of the management of irregular immigrants. The main findings show that increasing human rights violations of irregular migrants generate from a biopolitical mentality.
\end{abstract}

Keywords: Irregular immigrants; Foucauldian biopolitics; COVID-19 pandemic; Human rights; Malaysia.

JEL Classification: J83, J82, J80

a Corresponding author. Department of Southeast Asian Studies, Faculty of Arts \& Social Sciences, University of Malaya, 50603 Kuala Lumpur, Malaysia. Email: ocingir1@siswa. um.edu.my, Orcid ID: 0000-0001-9779-5863.

b Department of Southeast Asian Studies, Faculty of Arts \& Social Sciences, University of Malaya, 50603 Kuala Lumpur, Malaysia. Email: stkarasu@um.edu.my, Orcid ID: 0000-00034334-8026. 


\section{Introduction}

The varying levels of economic development in Southeast Asia cause active regional migration, thus making immigration studies an important research topic. After the 1980s, export-oriented growth strategies made Southeast Asian countries more dependent on migrant workers. Despite the influx of migrant populations, the living conditions of many immigrants in Southeast Asia have not improved and these people remain vulnerable. Immigrants, both documented and undocumented, are one of the most exploited and vulnerable groups on the social mobility ladder and they are important actors in the domestic economic sphere of the host economy. The sizeable undocumented immigrant population plays a significant role in both informal and formal economies, especially in the 3-D (difficult, dirty and dangerous) jobs. Undocumented workers are indispensable in sectors such as agriculture, construction, manufacturing and domestic services, where all these sectors are characterised by a lack of protection (Cholewinski \& Pecoud, 2009).

The Southeast Asian region has witnessed intense growth in migrant populations since the $19^{\text {th }}$ century, after the 1840 Anti-Slavery Convention raised the importance of labour needs, and many migration flows then took place in this region (Kaur, 2004). After the 1960s, many countries transformed significantly, shifting from a focus on agriculture to industrial production, with massive inflows of foreign direct investment (FDI) and trade. Relatively more liberal and developed Southeast Asian countries, namely Singapore, Malaysia, Thailand, Indonesia and the Philippines (being the pioneer members of the Association of Southeast Asian Nations [ASEAN], also known as ASEAN-5) encouraged industrial developments and tended to favour labour-intensive manufacturing in contrast to the Mekong River Delta countries, comprising of Cambodia, Laos and Vietnam. The ASEAN-5 investments triggered massive migration flows. While the migrants in the Mekong River Delta countries flowed into Thailand, migrants from other ASEAN countries moved to Malaysia and Singapore.

Malaysia in particular has become a major attraction for migrants, with an influx of irregular migrants (Kanapathy, 2008). Geographically porous borders allow a constant flow of irregular migration. Given this context, it is important to investigate the causes of the constant flow of irregular migration to Malaysia in the first place, because these are governed by various historical, economic and legal factors. Historically, migration 
is a regular and routine phenomenon in Southeast Asia (Ali, 2018) and international migration in Malaysia per se has been synonymous with the inflow of Indian and Chinese migrant workers in the $19^{\text {th }}$ and $20^{\text {th }}$ centuries. After many Southeast Asian countries gained their independence, migration flows continued within this region (Kaur, 2015). However, Malaysia has recently witnessed a huge migration of Indonesians and Filipinos into Sabah, triggered by economic factors such as differences in salaries, unemployment and underemployment as well as different labour market dynamics in Indonesia (Hugo, 1993) and the Philippines. While immigrant workers constitute a large chunk of the Malaysian labour force, social security and human rights frameworks for this group of people are rather weak and not well-developed (Gomez \& Ramcharan, 2018; Kassim, 1996; Kaur, 2015; SUARAM, 2006). Even though irregular immigration lacks clarity of definition in the Malaysian legal system, immigrants with a regular and documented status can easily become irregular migrants for various reasons. These immigrants have long been a focus of study in human rights violations, social injustice and xenophobia, requiring detailed investigations to build the foundation for more solid and effective policies aimed at rightsbased approaches, which would then maximise the advantages to all parties involved and mitigate negative consequences.

The recent COVID-19 pandemic posed even greater challenges to migrants, especially the undocumented ones. According to the United Nations (UN) Secretary-General Antonio Guterres, it is regarded as the biggest crisis since the Second World War and could trigger the worst economic downturn since the Great Depression (Asian News International, 2020). Irregular migrants, as the most marginalised and vulnerable members in society, are one of the groups most affected by COVID-19, which has led to the securitisation of migrant workers in the region (Dollah \& Abdullah, 2018).

At this juncture, it is worth noting that undocumented immigrants in Malaysia are seen as biopolitical subjects by the state. Malaysia has the largest population of irregular immigrants in Southeast Asia and is a prominent actor because of a perceived biopolitical rationality imposed upon immigrants. With COVID-19, Malaysian government policies on migrant workers have become harsher in terms of regulation and management (Human Rights Watch, 2020a). These practices are biopolitical actions in the Foucauldian sense, particularly because undocumented migrants are easily 
arrested, deported or disciplined, and treated as biopolitical subjects by the Malaysian government for COVID-19 control. The implications are very broad and create what could be seen as a Foucauldian "truth regime", used to monitor and control the population. One good example is how COVID-19 related cellular applications implemented by governments in Indonesia and the Philippines monitor, record and manage the movement of people in public places and have access to private domains like cell phone cameras and user information (Lin et al., 2020). The creation of a kind of Foucauldian biopolitical regime enables for the establishment of a knowledge-power system that legitimises government actions. In fact, modern powers constantly implement biopolitical practices on their populations, with surveillance and monitoring techniques made more explicit and integrated, but these have become more visible in the actions taken against marginalised groups. As undocumented immigrants are unregistered, undefined and mobilised, they could pose a serious public health hazard.

Based on interviews with several civil society organisations in Sabah in 2020, various non-governmental organisation (NGO) reports as well as news coverage in the media on issues related to migrants, we argue that opportunities to increase control and surveillance have been taken by the government. These have resulted in the deterioration of the social, financial and psychological wellbeing of irregular migrants in Malaysia.

This paper is among the first systematic studies that examine biopolitical strategies and practices of the state in exerting direct and indirect effects on undocumented immigrants in Malaysia. During our fieldwork, we interviewed some Sabahan NGO representatives from Borneo Comrad, Cahaya Society and Angkatan Belia Islam Malaysia (ABIM) in July 2019, who raised concerns about the irregular immigrant communities in Malaysia and the need to respect human rights. As challenging as the living conditions of irregular migrants and the problems they face are, their situation has worsened under COVID-19. This study therefore investigates the biopolitical measures taken against these irregular migrants. By addressing the nexus between migration and biopolitics, we intend to investigate government policies pertaining to reproduction and governing networks on irregular immigrants using the Foucauldian biopolitics theory, scrutinising how monitoring techniques applied to irregular migrant workers enable the exercise of state power over the population. The present paper begins by examining migration trends and the position of irregular immigrants in 
Malaysia. It subsequently investigates the precautions taken by Southeast Asian countries, following which it examines how irregular immigrants are transformed into biopolitical subjects in a Foucauldian sense. Finally, the paper revisits how states, particularly Malaysia, regulate immigrants due to COVID-19 by reviewing its effects on immigrants and their relationship with biopolitics.

\section{Migration, Irregular Immigrants and Super-Diversity in Malaysia}

The notion of "super-diversity" offers a multidimensional perspective for complex administrative, legal, urban and sociological problems arising from ethnic diversity in global cities where immigrant flows are intense (Vertovec, 2007). Singapore and Kuala Lumpur are good examples where the population of immigrants are concentrated (Goh, 2019: 356). The Ministry of Human Resources of Malaysia (2019) reported that Malaysia has more than two million migrant workers from Indonesia, Nepal, Bangladesh, India, Myanmar, Pakistan, the Philippines, Vietnam, China, Thailand, Sri Lanka, Cambodia and Laos. At the same time, regional ethnic conflicts, such as the Moro conflicts and the Rohingya genocide, have caused refugee inflows and further increased Malaysia's diversity, requiring a new mode of management. Governments view and handle the migrants in "managed settlements" for cohesion, adaptation and integration policies (Vertovec, 2007: 1047), implementing harsher administrative techniques on the pretext that super-diversity may trigger instability. Tougher security measures were implemented on immigrants, the most vulnerable group. At the same time, their presence triggered insecurity locally, thus leading to their securitisation (Dollah \& Abdullah, 2018). Immigrants are thus seen as possible causes of or actors in existing malignancy. Malaysian government officials, for instance, have previously claimed that immigrants are the main reason for the increase in tuberculosis cases ("Illegal immigrants among", 2016). Such statements enable the demonisation of immigrants and the implementation of harsher management techniques.

International migration has significantly impacted Southeast Asia after the Second World War, affecting social, economic and political contexts, caused by developments in global transportation and the proliferation of mass media, changes in immigration policies and growing gaps between regions with labour shortages and labour surplus (Hugo, 2004: 28-70). In 
addition, globalisation and informatisation have led to a rapid transformation throughout the world, along with rapidly growing consumer culture, production capacity, speed of communication and culture. In the face of this, governments have encountered difficulties in border control and managing sovereignty (Castells, 2010), with mass migration leading to more intense border and surveillance mechanisms (Ananta \& Arifin, 2004: 1-27).

In general, migration movements in Southeast Asia exhibit a pattern of flow from less developed countries to relatively developed ones, related to greater economic development and integration (Stahl, 2001). Post-1995, migrant workers shifted their focus from agriculture to production or operation (Devadason \& Chan, 2014). Migrant workers, particularly from South Asia, flowed into Malaysia after new policies on migration were introduced (Kaur, 2010). While the main destinations for immigrants in Southeast Asia are Malaysia, Singapore, Brunei and Thailand, Malaysia is particularly prominent (Kaur, 2010: 6-19). The World Bank estimates that Malaysia had 2,331,751 foreign-registered migrants and 717,281 irregular migrants in 2019 (Loh et al., 2019). Kaur (2010) claims that Malaysia has three million migrant workers, but only 2.2 million of them are registered.

According to Malaysian law, irregular immigrants are those who enter the country without an official permit, whose visas have expired or been cancelled but do not leave, refugees and asylum seekers. At this point, it is worth noting that the notion of irregular migration has no universal definition. For our purposes, the International Organization for Migration (IOM) (2021) describes irregular migration as a "movement of persons that takes place outside the laws, regulations, or international agreements governing the entry into or exit from the state of origin, transit or destination".

The presence of super-diversity is exacerbated by the presence of asylum seekers and refugees. Malaysia did not ratify or sign the 1951 Geneva Convention on the status of refugees or the amended 1967 Protocols. Hence Malaysia does not have a legal framework for asylum seekers or refugees which allows them to work or be educated legally. Thus, the United Nations High Commissioner for Refugees (UNHCR) is the organisation that defines those who are categorised as refugees and asylum seekers (Ishan Jan, 2013). According to the UNHCR (2020), 177,800 refugees and asylum-seekers live in Malaysia as of April 2020. 
The lack of efficient migrant worker regulations has led migrants to enter the country through irregular channels. According to the International Labour Organization (ILO) and IOM report (see ILO \& IOM, 2017), irregular migration is easier, cheaper and smoother. The existing liberal immigration policy between independence and 1994 was changed in 1995, in pursuit of new development goals and "Vision 2020". The new migration framework targeted more control over labour migration, aiming to govern dependence on foreign workers. A new "Special Task Force on Foreign Labour" was established to recruit and organise low-skilled foreign workers (Kaur, 2015).

With the Asian Financial Crisis in 1997, the Malaysian government applied harsh policies against undocumented migrants and aimed to control irregular migration, deported undocumented workers and blocked the renewal of work permits. Amnesty programmes allowed undocumented migrants to depart without penalty, and subsequently, measures to combat irregular migration were strengthened, work permit systems based on just offshore recruitment enforced and detention camps established to hold undocumented migrants (Kassim, 1996). The revised Immigration Act 1997 tightened migration regulations and toughened the penalties for undocumented migrants, which transformed them into "criminals" who could be punished with caning, imprisonment for up to five years and six strokes of the cane (Kaur, 2015). In 2004, the Malaysian government decided to repatriate more than a million undocumented migrants, using the Ikatan Relawan Rakyat Malaysia (People's Voluntary Corps) to support operations against undocumented migrants. However, this agency was reported to have engaged in many human rights violations against irregular migrants (SUARAM, 2006).

In Southeast Asia, generally, most immigrants live in crowded dwellings (Human Rights Watch, 2020a; Zolkepli, 2020), inferior in terms of hygiene and cleanliness. In the wake of COVID-19, irregular immigrants have had to continue to work daily jobs, not being covered by employment regulations and lacking comprehensive social security protection. Regular migrant workers can lose their regular and legal migrant status if they do not abide by the law, making them extremely vulnerable in legal terms and most likely the worst affected group by the COVID-19 pandemic - in particular the irregular migrants. 


\section{COVID-19, Southeast Asia and Malaysia}

Some Southeast Asian countries, including Singapore, Malaysia, Vietnam and Thailand, announced their first COVID-19 cases by the end of January 2020, owing to their close connections with China. Most, with the exception of Singapore and Vietnam, were not able to respond quickly (Kurlantzick, 2020), since they were either poor or middle-income states, with less effective public health systems to track COVID-19 patients and dependent on tourism, trade with developed countries and export-oriented industries such as manufacturing.

Most were late in banning travel and trade to and from China and did not pay much attention to health experts' warnings and advice because many such diseases that spread from China in the past were successfully contained. However, when the infectious nature of the illness became apparent, most countries began to take precautions. Some immediate measures were border closures, enforced quarantines and social distancing. Export-focused economies and emerging markets were badly affected due to their dependence on global and regional trade flows as well as tourism (Kurlantzick, 2020).

As can be seen in Table 1, the spread of Covid-19 varies considerably. Governments have operated tentative, experimental and innovative approaches with different outcomes. The Mekong River countries managed COVID-19 relatively successfully and kept the numbers low with early and tough restrictions. Indonesia and the Philippines were more seriously affected, and various problems arose in the pandemic management process. Malaysia and Singapore, on the other hand, did not fully succeed in reducing the number of cases, although they employed important restrictions and measures such as quarantines and movement control orders (MCOs) (Center for Strategic and International Studies, 2020).

Despite Indonesia having a younger population, the fatality rate of 9 per cent was one of the highest in the world. According to Panda Riono, an epidemiologist at the University of Indonesia, age and existing illnesses such as hypertension and diabetes made contracting the virus more deadly. Additionally, limited health capacity and preparation at early stages made matters worse in Indonesia. Malaysia, Singapore, Thailand and Cambodia closed their borders and applied strict measures such as shutting down nonessential businesses and encouraging home-working systems (Maulia \& Tani, 
2020). Myanmar's state counsellor, Aung San Suu Kyi, stated in March 2020 that "until now, no one in our country is infected with COVID-19" (Kyi \& Htet, 2020).

Table 1: Southeast Asia COVID-19 Tracker

\begin{tabular}{lcccccc}
\hline Countries & Cases & $\begin{array}{l}\text { Cases } \\
\text { (Last 24 } \\
\text { hours) }\end{array}$ & Deaths & $\begin{array}{l}\text { Total Fully } \\
\text { Vaccinated }\end{array}$ & $\begin{array}{l}\text { Percentage } \\
\text { Fully } \\
\text { Vaccinated (\%) }\end{array}$ & $\begin{array}{l}\text { Cases } \\
\text { Per } \\
\text { Million }\end{array}$ \\
\hline World & $196,922,145$ & 826,451 & $4,203,461$ & $1,121,034,077$ & 14.4 & 25,246 \\
China & 104,922 & 68 & 4,848 & No Data & No Data & 73 \\
USA & $34,771,355$ & 93,943 & 612,238 & $163,868,916$ & 49.5 & 105,048 \\
Indonesia & $3,372,374$ & 41,168 & 92,311 & $19,669,222$ & 7.3 & 12,583 \\
Philippines & $1,580,824$ & 14,157 & 27,722 & $7,835,715$ & 7.5 & 15,070 \\
Vietnam & 133,405 & 9,765 & 1,022 & 546,402 & 0.6 & 1,396 \\
Thailand & 578,375 & 17,345 & 4,679 & $6,317,710$ & 9.1 & 8,334 \\
Myanmar & 294,460 & 10,361 & 8,942 & $1,527,284$ & 2.9 & 5,517 \\
Malaysia & $1,095,486$ & 16,840 & 8,725 & $6,104,836$ & 19.6 & 35,112 \\
Cambodia & 76,585 & 668 & 1,375 & $4,670,954$ & 29.2 & 4,784 \\
Laos & 5,919 & 244 & 6 & 832,673 & 11.3 & 804 \\
Singapore & 64,861 & 272 & 37 & $3,158,737$ & 56.3 & 11,558 \\
Timor- & 10,695 & 160 & 26 & 86,759 & 6.5 & 7,982 \\
Leste & & & & & & 777 \\
Brunei & 333 & 0 & 3 & 24,052 & 5.6 & 773 \\
\hline
\end{tabular}

Source: Center for Strategic and International Studies (July 31, 2021).

When Vietnam took strict preventive measures, local gatherings such as kickboxing events continued in Thailand even in the middle of March. The Thai government was reluctant to restrict movement and slow down economic activities ("Thailand Job Loses", 2020). In Malaysia, 16,000 people clustered at Sri Petaling Mosque, following which Covid-19 cases began to increase sharply. Some worshippers came from Indonesia, Thailand and as far away as China to attend the gathering (Maulia \& Tani, 2020). The Ministry of Health Singapore (2020) reported that immigrant workers accounted for 47 per cent of cases, as they lived in overcrowded spaces. Restrictions did not work effectively in Malaysia, Singapore and Thailand, especially in areas with a higher concentration of immigrants. 
The Malaysian government announced 1,095,486 COVID-19 cases as of 31 July 2021 (See Table 1). The first MCO was enforced on 18 March, and it was extended four times until 9 June (Hassan, 2020), banning all gatherings, overseas travel and foreign tourists. All economic activities, except essential ones, ceased. Malaysians who recently returned from abroad were required to undergo health tests and self-quarantine for 14 days, as implemented under the Prevention and Control of Infectious Disease Act 1988. Although the Malaysian government loosened many restrictions related to economic sectors from 1 May, after the Sabah state elections, a sharp rise in cases triggered the conditional MCO on 14 October (Martinus, 2020).

In general, the COVID-19 pandemic resulted in the extension of power of governments, restricting freedom of the press and movement while limiting access to information in Southeast Asia. Khoo (2020) identified six major regional trends. The first trend appears to be the rise of authoritarianism. Southeast Asia has already suffered from authoritarian governments (Croissant \& Lorenz, 2018, p. 8-10) and its main governing models are security-based approaches and the suppression of civil rights. COVID-19 measures have aggravated core human rights abuses (Amnesty International Malaysia, 2020). The second trend is the lack of regional unity. Regional intergovernmental organisations and frameworks were unable to respond to the crisis effectively, and their coordination and collaboration was insufficient, with ASEAN unable to adequately manage the crisis, the weaknesses of its institutional structures made visible ("Whither ASEAN unity", 2020).

The third trend is increased militarisation. In most regional countries, military services have taken charge of the lockdown process (Yusof, 2020). Demonstrations in Thailand were suppressed by the military and a military coup came to power in Myanmar. The fourth trend is the lack of effective governance, with those related to human rights, defence, education and working conditions suppressed. Governments have ignored transparency and coherent, knowledge-based policies while becoming more centralised decision-making actors. In Indonesia, the public has criticised its poor governance structures, which became a trending topic in Indonesian social media, with the hashtag "indonesiaterserah" (whatever Indonesia) widely used on several social media platforms ("Hashtag '\#Indonesia?", 2020).

Rising disparities are the fifth trend. Lockdowns overwhelmingly harmed and oppressed the lower classes, particularly migrant workers. 
The use of technology is the sixth trend. While tracing apps are intended to enforce lockdowns, they can also compromise one's personal privacy and data security (Batumalai, 2020). Many mobile applications require personal information, and the information uploaded to these applications are processed by governments, causing the reliability and transparency of these applications to be questioned.

\section{Mapping the Biopolitics of Immigrants in Malaysia During COVID-19 Pandemic}

Foucault gave three seminars on public health in Brazil in October 1974. He used the notion of "biopolitics" for the first time in his second seminar, "The Birth of Modern Medicine", to define the transformation of social medicine (Foucault, 2001). According to Foucault, from the 17th century onwards, "life" became a concept that was to be protected, managed and developed (Foucault, 1978). In short, biopolitics is an apparatus used to discipline the individual and the body, controlling the population beyond life (Lemke, 2011). Disciplinary mechanisms emerging in the 17 th century saw the emergence of different types of power that envisaged the control of individual bodies through techniques such as surveillance, control, recording, spatial arrangement and classification (Foucault, 2003: 36). Biopolitics leans towards a mode of power that regulates life (Foucault, 2009). While examining the development of medicine, Foucault developed an important thought regarding epidemics, where in the $19^{\text {th }}$ century, "urban medicine" arose from the need to unify the city into a coherent and homogeneous shape, governed by a "single, well-ordered authority," as a result of overpopulation and industrialisation (Foucault, 2003: 326). Thus, the body is a biopolitical reality and medicine is a biopolitical strategy (Foucault, 2000: 137).

From the 1890s, official institutions were established to screen children for epidemics, and there was a rapid institutionalisation of actions against contagious diseases and epidemics (Rosen, 1993). As Foucault stated, the poor were initially targeted through medical surveillance to preserve the continuity and importance of the workforce, following which "surveillance medicine" encompassed the entire population within surveillance networks at the beginning of the 20th century (Nadesan, 2008: 103), emphasising the systematic observation of the population and also including a type of social 
surveillance (Armstrong, 2002). In particular, a kind of social spatiality was created to prevent the spread of epidemics, significantly increasing new occupations in home care, public cleaning and nutrition (Nadesan, 2008: 106). In this period, governing through medicine focused on two main axes: the first was statistical knowledge, and the second was administration (Rose, 1999). In the $20^{\text {th }}$ century, document collection, analysis and information on epidemics have raised the importance of public health management. More objective and clear statistical information emerged, based on community surveillance with institutionalisation and scientific medical information. However, at the same time, it established a political regime which surveyed and managed the population.

This paper applies the "biopolitics of migration" as the conceptual underpinning of the discussion. While the term "biopolitics" referred to management and governing of life in the 1970s, the "biopolitics of migration" refers to the administration of migrants, spatial configurations and any form of power relations (Wiertz, 2020). In Southeast Asia, immigration control regimes have employed Foucauldian disciplinary power (Nah, 2012). Malaysia has implemented the biopolitical administration of immigrants due to COVID-19.

The biopolitics of medical production are good examples for us to expose the web of power in everyday life (Ong, 1995). The pandemic also uncovers power relations, in how the government exerts power over marginal groups through the implementation of "national crackdowns" and harsh punishments of irregular immigrants in Malaysia - a biopolitical exercise of disciplinary power (Nah, 2012). The bodies of irregular immigrants have become a biopolitical reality and the MCO has transformed into a biopolitical strategy. In addition, the Malaysian government has refused to test undocumented migrants for COVID-19, which has transformed them into biopolitical subjects, steerable and regulatable by power.

Biopolitical order also creates a type of surveillance and contention regime (Salter, 2006). Tracing applications and new information technologies allow people to be monitored by governments, thus allowing governments to implement quarantines or lockdowns efficiently (Information Commissioner's Office, 2020). However, these tools can also cause privacy violations and produce security crises since governments may, among other things, access the addresses of people, what they do, how much they do and other private information (Bell, 2020). Data collection, classification, 
management and usage are inherently important for governing the public at this time, and biopolitical measures can easily become a government apparatus for restricting individual rights. Southeast Asian governments have used such technology, primarily cell phone data, to monitor the movements of citizens and to curb the spread of COVID-19, thus also exercising surveillance and disciplinary power over them. At this juncture, COVID-19 has become an excuse for governments to increase their powers over society (Roth, 2020). These surveillance and control technologies also play an important role in controlling irregular immigrants, since mandatory "check-ins" push irregular immigrants away from public spaces, for fear of being detained by the authorities. Thus, immigrants are caught in a limbo and distance themselves from public spaces.

Asrin Utong, a civil activist from Cahaya Society from Sandakan, Sabah, raised concerns about the conditions of irregular immigrants, who cannot leave their homes for fear of being arrested and sent to temporary detention centres (Pusat Tahanan Sementara, PTS). Various negative statements made by policymakers also cause them to be stigmatised and demonised by the local community. The fear amongst irregular immigrants escalated as new PTSs were built in Sabah, which has the highest concentration of irregular immigrants nationwide (Miwil, 2020). The PTSs are meant to manage amnesty operations and deportations, and as such, we can say that a biopolitical rationality runs within these centres. Disciplinary punishments such as physical violence or locking immigrants away for a long time may constitute the most important examples of biopolitical practices.

COVID-19 has allowed the Malaysian government to tackle irregular immigrants more strictly. Irregular migrants have not been able to benefit from healthcare services, economic subsidy programmes or COVID-19 tests - some do not want to be tested for fear of being fired or deported (Wahab, 2020). At this point, their bodies have become a biopolitical entity. Under the pretext of public health and security (Koalisi Buruh Migran Berdaulat, 2020), irregular immigrants were locked into detention centres with deplorable conditions, lacking sufficient space and proper hygiene, thereby being exposed to high risks. Hundreds of irregular immigrants were taken into custody, photographed living in detention within a very narrow area with barbed wires - the image reflects the biopolitical rationality applied by the state to irregular immigrants, which transformed into online protests; 
especially from social media users who criticised the approach used by the government (Lund, 2020). The blog MigranJugaManusia (migrants are also humans) became a trending topic on social media.

\section{Undocumented Immigrants in Malaysia During the COVID-19 Pandemic}

The Malaysian government needed to tackle the COVID-19 crisis with great urgency, becoming more authoritative and dominant by increasing its surveillance and control techniques, thus making society more steerable. At this point, the pressure on vulnerable and minority groups also increased, similarly to irregular immigrants. The government has administered different management rationalities on three different immigrant groups.

The first group (one of the most affected ones) includes irregular immigrants currently residing in Malaysia. This group comprises of Indonesians (the largest nationality), Bangladeshis, Nepalis, Burmese, and Filipinos. Indonesian immigrants frequently come to Malaysia due to its geographical proximity and cultural similarity, mostly from Sulawesi and Kalimantan, flowing into East Malaysia through its porous borders (Hugo, 1993). To prevent these unregistered inflows, the Malaysian government has increased border patrols and control mechanisms, although these measures could not stop their flow.

Sabah, due to its proximity to Indonesia and the Philippines, has the largest number of irregular immigrants, and they posed a serious challenge especially after the 2020 state elections, when active COVID-19 cases in Sabah constituted more than half of all active cases in Malaysia (“COVID-19: Sabah Terus", 2020). Kota Kinabalu, Sandakan, Semporna, Lahad Datu, and Tawau were particularly affected, which was where the irregular migrants were mainly concentrated. Hospital, medical and aid capacity was driven to the limits. As a response, the government mobilised medical staff, public officers and NGOs to help. As of 23 October 2020, the number of active cases reached 5,624, and the most affected groups were irregular immigrants, with many hotspots involving them (Ravindran, 2020). As a consequence, irregular immigrants were blamed by the government for Sabah's COVID-19 escalation (Loheswar, 2020), which caused immigrants to become more marginalised and vulnerable, with all irregular immigrants who had been arrested being screened and placed in PTSs. 
Similarly, 395 Filipino irregular immigrants who were held in the PTSs were repatriated. According to officials, the number of deported irregular immigrants as of July 2020 was 4,751 ("PATI Filipina Terkandas", 2020). Despite those strict measures, some Indonesian immigrants escaped the detention centres due to various reasons such as the risk of job losses and poor conditions in those centres. Doctors Without Borders stated that the centres have become hotspots of cases due to overcrowding (Nortajuddin, 2020).

The second irregular migrant group investigated are the Rohingya refugees, who number 102,960 (UNHCR, 2021). In an attempt by one group to land, the Malaysian navy pushed their overloaded boats back to the sea on 16 April 2020, and justified its actions by stating that refugees would bring COVID-19 cases into the country, under the pretext of the MCO. However, Malaysia's policy contravenes international commitments not to return anyone to a place where they could face the risk of torture or other ill-treatment (Human Rights Watch, 2020b).

Recently, news emerged that some Rohingya refugees apparently demanded citizenship and equal rights for their community in Malaysia, which caused outrage among Malaysians (Rodzi, 2020). Many online petitions calling for the deportation of Rohingya refugees were signed and hate speech was expressed on social media against them (Nortajuddin, 2020). The Malaysian Prime Minister announced that they would not no longer accept any Rohingya refugees ("Malaysia calls on UNHCR", 2020), calling on other members of ASEAN and the UNHCR to be more effective in preventing new refugee flows and to play active role at a governmental level to curb the phenomenon. He claimed that they were a very serious security threat to the region and stressed that it was essential for ASEAN to take tougher measures against irregular migration.

Another refugee minority that has been badly affected by COVID-19 pandemic are the Chin refugees from Myanmar, who claimed that the state has arrested 73 Chin refugees during the $\mathrm{MCO}$, and some have been subjected to deportation or detention (Razak, 2020). They also pointed out that human rights violations against refugees will make them more vulnerable and that they expect the UNHCR to protect their human rights vigorously.

The third group involves other irregular immigrants who enter via irregular routes and channels. The main difference between the third group 
and the current irregular immigrants in Malaysia are the practices imposed upon the immigrants. The irregular immigrants who are already in Malaysia may be legalised via amnesty operations. However, new immigrants face very strict consequences. The government, as such, has decided to tighten border security. In May 2020, 850 irregular immigrants and 153 boat captains were arrested for trying to sneak into Malaysian waters irregularly (Anis, 2020).

Immigrants face various challenges emanating from their vulnerability (Welsh, 2020). As mentioned by NGOs and researchers on irregular immigrants in Sabah, they already lack access to fundamental human rights, but COVID-19 has raised the importance of access to healthcare, a situation which was very grey for a long time (Somiah et al., 2020) Subsequently, the Malaysian government changed its decision several times regarding who should take responsibility for the payment of migrant workers' COVID-19 tests. Initially, the Social Security Organisation (SOCSO) was to cover these costs, provided that they contributed to this fund (Bedi \& Anis, 2020). However, irregular migrants are not covered under this provision. Even though the Malaysian government announced various economic stimulus measures, these do not protect irregular migrants (Sandanasamy et al., 2020). Employment-related consequences surmounted during this period. According to an ILO report, common violations of undocumented migrant workers' labour rights during the COVID-19 pandemic included "unfair termination; unpaid wages; poor living conditions; employers requiring workers to continue working in jobs that are non-essential; and uncertainty about employment status due to limited contact with employers" (Sandanasamy et al., 2020). They are also among the most helpless members of society due to the stoppages in most sectors, and therefore, many of them required support for food and shelter.

The protection of undocumented migrant workers involved in essential services throughout the MCO is another concern. Most employers in the manufacturing sector related to essential services violate labour rights and do not follow MCO rules on social distancing, living conditions, working hours, health and occupational safety. For instance, rubber gloves are a fundamental form of personal protective equipment; however, the rubber glove sector itself obviously did not meet these MCO requirements to protect labourers' health and ensure social distancing (Sandanasamy et al., 2020), thus creating the largest COVID-19 cluster (the Teratai cluster involving Top Glove) in November 2020. 
According to human rights activists, irregular migrants have become the most victimised and discriminated group (CIVICUS, 2020). SUHAKAM, the Malaysian Human Rights Commission noted that despite promises that immigrants would not be arrested, human rights violations still occurred (SUHAKAM, 2020). SUHAKAM's press release stressed that arrests of irregular migrants should be stopped and argued that the detention of immigrants was dangerous for both immigrants and public health - instead, the focus should be on providing health protection to these immigrants (Joseph, 2020).

At this stage, it should be highlighted that border and visa controls are legitimately exclusively determined by national governments. However, states do have the responsibility to protect refugees, asylum-seekers and those fleeing persecution stemming from breaking the rules of international law. As states tackle irregular migration, assembling all migrants under the same roof and transforming them into biopolitical subjects will make them more fragile and unprotected, thus violating their rights to a life free from fear, harassment or discrimination. In particular, asylum rights of refugees and the right to life of immigrants (which arise from universal human rights agreements and general principles of law) were violated in Malaysia during the COVID-19 period.

The Malaysian government has developed different policies to handle irregular migrants' problems during the MCO. In late March 2020, Senior Minister of Security, Dato' Sri Ismail Sabri Yakoob (the current Prime Minister), stated that "illegal migrants should not concern about their status because Malaysian government has decided not to make it a problem and intends to focus on combating the pandemic" ("Human Resources Ministry releases", 2020), by supplying free-of-charge treatment for all foreigners during the $\mathrm{MCO}$, irrespective of their immigration status ("MCO: out-ofwork foreigners", 2020). However, at the end of April 2020, hundreds of undocumented migrants were arrested in the centre of Kuala Lumpur and relocated to detention centres or special prisons (Sukumaran \& Jaipragas, 2020). Indonesian detainees, upon recovery, were deported by the Malaysian government using COVID-19 as an excuse (Nortajuddin, 2020). About 2,861 Indonesian irregular migrants who tested negative were also deported at the beginning of June (Radhi, 2020). 


\section{Conclusion}

In this paper, the authors have outlined migration trends and the status of undocumented immigrants, the main measures taken to manage the COVID-19 crisis in Southeast Asia and how they have since become biopolitical subjects in Malaysia. Immigrants, in particular their lives and bodies, are targeted by the authorities. Biopolitics is an important theoretical concept in understanding the nature of power, its interactions, relationships and consistency. Using this theoretical framework, we aim to understand how biopolitics is lived, experienced and challenged by irregular immigrants and to enrich the theoretical discussion of the biopolitics of migration.

Government measures taken during the pandemic gave the authorities the opportunity to increase control and surveillance, in other words adopting a biopolitical mentality. This worsened the living conditions and wellbeing of irregular migrants in Southeast Asia in general, and in Malaysia in particular. Moreover, it has deepened their legal, economic, social and psychological problems, and limited their access to basic needs. Irregular migrant workers fall into the lowest stratum in the labour force, as day labourers and stigmatised low paid workers. Ironically, their "invisible" entities were transformed into possible threats to public health by the authorities. For example, irregular migrants in Sabah were supposedly the reason for the spreading cases. Although irregular migrants contribute significantly to the growth of the economy, they are ignorable, controllable and eradicable, being possible threats and targets in emergencies as a result of this biopolitical mentality.

COVID-19 has been utilised in biopolitical terms by Southeast Asian states to govern their societies, with biopolitical practices and mentalities applied to immigrants. Biopolitics is not only a security policy but also an administrative matter. It is not only suppressive but suffusive and coordinative. Along with the modern state, it has become a management technology that gains political power from its internality. This new form of power has transformed life patterns from being regulated, controlled and reproduced into the form desired by the power. The modern political matrix is trapped in a triangle of security, population and power. Life, the object of power, is biologised and transformed into numerical data. In the biopolitical sense, as the state plays a deeper part in the lives of the population, where deeper and more encompassing administration technologies have become 
operative in practice. The biopolitical mentality plays a more impressive, regulatory and formative role over the population. At this juncture, COVID-19 reminds us of the importance of people-centred policies, which are not only related to universal human rights, ethics and moral principles, but also the potential risks of becoming COVID-19 carriers. No one is excluded from getting infected and preventing the spread of COVID-19 should be taken seriously. This kind of solution should involve both rational and ethical purposes.

\section{Acknowledgement}

We would like to thank our anonymous reviewers for their insightful comments and suggestions.

\section{Conflicts of Interest}

The authors declare no conflict of interest.

\section{References}

Ali, S.H. (2018). A People's History of Malaysia. Petaling Jaya: SIRD.

Amnesty International Malaysia (2020). Perikatan Nasional government must place human rights at the heart of its policies. Retrieved from https://www.amnesty.my/2020/06/15/perikatan-nasional-governmentmust-place-human-rights-at-the-heart-of-its-policies/

Ananta, A., \& Arifin, E. N. (2004). Should Southeast Asian borders be Opened. In Ananta, A., \& Arifin, E. N. (Eds.), International Migration in Southeast Asia (pp. 1-27). Singapore: ISEAS.

Anis, M.N. (2020, June 17). 10 more illegal immigrants caught trying to sneak into the country. The Star. Retrieved from https://www.thestar. com.my/news/nation/2020/06/17/10-more-illegal-immigrants-caughttrying-to-sneak-into-the-country

Armstrong, D. (2002) A New History of Identity: A Sociology of Medical Knowledge. Houndmills, UK: Palgrave.

Asian News International (2020, April 18). UN warns Covid-19 could trigger worst downturn in global economy since Great Depression. Hindustan Times. Retrieved from https://www.hindustantimes.com/world-news/unwarns-covid-19-could-trigger-worst-downturn-in-global-economy-since- 
great-depression/story-VFkt92TXuFCZQuyXGnkHDP.html

Batumalai, K. (2020, July 16). Central contact tracing App may threaten data protection, SELangkah Creator Says. CodeBlue. Retrieved from https:// codeblue.galencentre.org/2020/07/16/central-contact-tracing-app-maythreaten-data-protection-selangkah-creator-says/

Bedi, R., \& Anis, M. N. (2020, May 5). COVID-19 screening: SOCSO coverage for foreign workers who contribute to the organization. The Star. Retrieved from https://www.thestar.com.my/news/ nation/2020/05/05/covid-19-screening-socso-coverage-for-foreignworkers-who-contribute-to-organisation

Bell, G. (2020, April 12). We need mass surveillance to fight covid-19 but it doesn't have to be creepy. MIT Technology Review. Retrieved from https:/www.technologyreview.com/2020/04/12/999186/covid-19contact-tracing-surveillance-data-privacy-anonymity/

Castells, M. (2010). The Information Age Economy, Society, and Culture Volume II: The Power of Identity (pp.303-304). Sussex: Wiley-Blackwell. Center For Strategic and International Studies. (2020, December 17). The Latest on Covid-19 in Southeast Asia. Retrieved from https://www.csis. org/blogs/latest-covid-19-southeast-asia/latest-covid-19-southeast-asiadecember- 17

—. (2021, July 31). Southeast Asia Covid-19 Tracker. Retrieved from https://www.csis.org/programs/southeast-asia-program/southeast-asiacovid-19-tracker-0

Cholewinski, R., \& Pecoud, A. (2009). Migration and Human Rights: The United Nations Convention on Migrant Workers' Rights. Cambridge: Cambridge University Press.

CIVICUS. (2020, April 27). Migrants are amongst the first to be victimised and discriminated during the pandemic. Retrieved from https://www. civicus.org/index.php/media-resources/news/interviews/4389-malaysiamigrants-are-amongst-the-first-to-be-victimised-and-discriminatedduring-the-pandemic

COVID-19: Sabah terus dibadai, kes aktif hampir enam ribu (2020, October 16). Bernama. Retrieved from https://www.bernama.com/bm/rencana/ news.php?id=1890496.

Croissant, A., \& Lorenz, P. (2018). Comparative Politics of Southeast Asia an Introduction to Governments and Political Regimes. New York: Springer. 
Devadason, E.S., \& Chan, W.M. (2014). Policies and laws regulating migrant Workers in Malaysia: A critical appraisal. Journal of Contemporary Asia, 44(1): 23. https://doi.org/10.1080/00472336.2013.826420.

Dollah, R., \& Abdullah, K. (2018). The securitization of migrant workers in Sabah. Malaysia. Journal of International Migration and Integration, 19(3): 717-35. https://doi.org/10.1007/s12134-018-0566-0.

Foucault, M. (1978). The History of Sexuality, Volume 1: An Introduction. New York: Pantheon Books.

- (2001). The birth of social medicine. In J. Faubion (Ed.), Power (p.137). New York: The New Press.

—. (2003). "Society Must Be Defended": Lectures at the Collège de France, 1975-1976 (pp.36-38). New York: Picador.

- (2009). Security, Territory, Population: Lectures at the Collège de France, 1977-1978. New York: Palgrave Macmillan.

Goh, D.P.S. (2019). Super-diversity and the bio-politics of migrant worker exclusion in Singapore. Identities, 26(3): 356-73. https://doi.org/10.108 0/1070289X.2018.1530899.

Gomez, J., \& Ramcharan, R. (Eds.) (2018). Introduction. In The Universal Periodic Review of Southeast Asia Civil Society Perspectives (pp.1-15). Petaling Jaya: SIRD.

Hassan, H. (2020, May 10). Malaysia's control movement order extended for another four weeks to June 9. The Straits Times. Retrieved from https:// www.straitstimes.com/asia/se-asia/malaysias-conditional-movementcontrol-order-extended-for-another-four-weeks-to-june-9

Hashtag '\#Indonesia? Terserah!!' takes the country's social media by storm. (2020, May 27). The Star. Retrieved from https://www.thestar.com. my/tech/tech-news/2020/05/27/hashtag-indonesia-terserah-takes-thecountrys-social-media-by-storm

Hugo, G. (1993). Indonesian labour migration to Malaysia: Trend and policy implications. Southeast Asian Journal of Social Science, 21(1): 36-70. https://doi.org/10.1163/030382493X00035.

. (2004). Migration in Southeast Asia since World War II. In Ananta, A. \& Arifin, E.N. (Eds). International Migration in Southeast Asia. (pp.28-70), Singapore: ISEAS.

Human Rights Watch. (2020a, March 24). Malaysia: Migrants, stateless at extra risk from virus. Retrieved from https://www.hrw.org/ news/2020/03/24/malaysia-migrants-stateless-extra-risk-virus 
(2020b, April 18). Malaysia: Allow Rohingya refugees ashore Covid-19 no basis for pushing back boats. Retrieved from https://www. hrw.org/news/2020/04/18/malaysia-allow-rohingya-refugees-ashore

Human Resources Ministry releases FAQ during MCO period (2020, March 20). The Star. Retrieved from https://www.thestar.com.my/news/ nation/2020/03/20/human-resources-ministry-releases-faq-during-mcoperiod

Illegal immigrants among causes of tuberculosis spread - Dr Hilmi. (2016, April 3). Astro Awani. Retrieved from http://english.astroawani.com/ malaysia-news/illegal-immigrants-among-causes-tuberculosis-spreaddr-hilmi-100842

ILO and IOM. (2017). Risks and rewards: Outcomes of labour migration in South-East Asia. Bangkok: International Labour Organization. Retrieved from http://apmigration.ilo.org/resources/risks-and-rewards-outcomes-oflabour-migration-in-south-east-asia/at_download/file1

IOM. (2021) Irregular migration. Retrieved from https://www.iom.int/keymigration-terms\#Irregular-migration

Information Commissioner's Office. (2020, April 17). Information commissioner's opinion: Apple and google joint initiative on COVID-19 contact tracing technology. Retrieved from https://ico.org.uk/media/ about-the-ico/documents/2617653/apple-google-api-opinion-finalapril-2020.pdf

Ishan Jan, M.N. (2013) Asylum seekers and the right to work. In A.A.A. Mohamed, F.B.S. Baig, M.S. Mallow \& M.N.I. Jan (eds.), Foreign Workers: The Law and Practice in Malaysia (pp. 389-414). Current Law Journal Publication.

Joseph, J. (2020, May 4). Migrant workers: Protection, not detention. Retrieved from https://www.bfm.my/podcast/evening-edition/eveningedition/migrant-workers-protection-not-detention-\#.XrEB_KXxFZY. twitter

Kanapathy, V. (2008). Controlling irregular migration: The malaysian experience, ILO Asian Regional Programme on Governance of Labour Migration Working Paper No.14. Retrieved from https://www.ilo.org/ wcmsp5/groups/public/---asia/---ro-bangkok/documents/publication/ wcms_160587.pdf

Kassim, A. (1996, March 3-6). Labour Migration in ASEAN: Issues and Problems from the Malaysian Perspective [Paper Presentation]. Seventh 
Southeast Asia Forum ASEAN: Shared Identities, Interests and Values, Kuala Lumpur, Malaysia.

Kaur, A. (2004). Wage Labour in Southeast Asia Since 1840: Globalization, The International Division of Labour, and Labour Transformations, (pp. 3-4). New York: Palgrave Macmillan.

- (2010). Labour migration in Southeast Asia: migration policies, labour exploitation and Regulation. Journal of the Asia Pacific Economy, 15(1): 6-19. https://doi.org/10.1080/13547860903488195.

- (2015). Malaysia labour migration, irregular movements and regional policies. In Pietsch, J. \& Clark, M. (Eds.), The Migration and Integration in Europe, Southeast Asia, and Australia (pp. 75-98). Amsterdam: Amsterdam University Press.

Khoo, Y.H. (2020, June 17). RCAPS seminar: Politics and international relations in Southeast Asia amid the COVID-19 pandemic, [Paper Presentation]. Ritsumeikan Asia Pacific University, Webinar. Retrieved from https:/www.youtube.com/watch?v=Lw2N6_cBLaM\&ab_channel $=\%$ E7\%AB $\% 8 B \%$ E5\%91\%BD $\%$ E9\%A4\%A $\% \%$ E3\%82\%A2\%E3\%82 $\%$ B $8 \%$ E3\%82\%A2\%E5\%A4\%AA $\%$ E5\%B9\%B3\%E6\%B4\%8B\%E5\% A4\%A7\%E5\%AD\%A6-RitsumeikanAsiaPacificUniversity-

Koalisi Buruh Migran Berdaulat. (2020). Laporan: Tim pencari fakta tentang kondisi migran Indonesia yang dideportasi selama masa Covid-19 dari Sabah, Malaysia ke Indonesia, October 2020: Makassar. Retrieved from http:/www.solidaritasperempuan.org/sub/wp-content/uploads/2020/10/ Laporan-TPF-Buruh-Migran.pdf

Kurlantzick, J. (2020, April 17). Can Southeast Asia fend off the one-two punch of COVID-19, World Politics Review. Retrieved from https:// www.worldpoliticsreview.com/articles/28691/can-southeast-asia-fendoff-the-one-two-punch-of-covid-19

Kyi, A. P., \& Htet, S. S. (2020, March 16). State counsellor says Myanmar still free of COVID-19, Myanmar Times. Retrieved from https:/www. mmtimes.com/news/state-counsellor-says-myanmar-still-free-covid-19. html

Lemke, T. (2011). The government of living beings: Michel Foucault. In Biopolitics: An Advanced Introduction, (pp. 33-52). New York; London: NYU Press.

Lin, P., Knockel, J., Poetranto, I., Tran, S., Lau, J., \& Senft, A. (2020, December 21). Unmasked II: An analysis of Indonesia and the 
Philippines' government-launched COVID-19 Apps. Citizen Lab. Retrieved from https://citizenlab.ca/2020/12/unmasked-ii-an-analysisof-indonesia-and-the-philippines-government-launched-covid-19-apps/

Loh, W. S., Simler, K., Wei, K. T., \& Yi, S. (2019, March 28). Malaysia estimating the number of foreign workers (A report from the Labor Market Data for Monetary Policy Task). Washington: The World Bank. Retrieved from https://documents1.worldbank.org/curated/ en/953091562223517841/pdf/Malaysia-Estimating-the-Number-ofForeign-Workers-A-Report-from-the-Labor-Market-Data-for-MonetaryPolicy-Task.pdf

Loheswar, R. (2020, October 3). Muhyiddin: Undocumented migrants cause of Sabah's Covid-19 situation, more detention centres to be opened. Malay Mail. Retrieved from https://www.malaymail.com/news/ malaysia/2020/10/03/muhyiddin-undocumented-migrants-cause-ofsabahs-covid-19-situation-more-det/1909146

Lund, K. (2020, May 4). \#MigranJugaManusia online protest took place yesterday... Here's what happened. Retrieved from https://juiceonline. com/migranjugamanusia-online-protest-took-place-yesterday-heres-whathappened/

Malaysia calls on UNHCR to work with ASEAN in expediting resettlement process of UNHCR cardholders to third countries. (2020, June 26). The Edge Markets. Retrieved from https://www.theedgemarkets.com/article/ malaysia-calls-unhcr-work-asean-expediting-resettlement-process-unhcrcardholders-third

Martinus, D. (2020). Malaysia's Conditional MCO has been extended for another 2 weeks, Retrieved from https://sea.mashable.com/news/12973/ malaysias-conditional-mco-has-been-extended-for-another-2-weeks

Maulia, E., \& Tani, S. (2020, April 7). Indonesia in 'worst' position as coronavirus attacks ASEAN bloc. Asia Nikkei. Retrieved from https:// asia.nikkei.com/Spotlight/Asia-Insight/Indonesia-in-worst-position-ascoronavirus-attacks-ASEAN-bloc

MCO: out-of-work foreigners trying to sneak out of country. (2020, April 7). New Straits Times. Retrieved from https://www.nst.com.my/news/ nation/2020/04/581997/mco-out-work-

Ministry of Health Singapore. (2020, December 14). Measures to contain the Covid-19 outbreak in migrant worker dormitories. Retrieved from https:// www.moh.gov.sg/news-highlights/details/measures-to-contain-the-covid- 
19-outbreak-in-migrant-worker-dormitories

Ministry of Human Resources. (2019). Work and labour statistics, series

19. No. 1. March. Retrieved from http://myhos.mohr.gov.my/ebook/ istatistik1_2019/bil1_2019.pdf

Miwil, O. (2020, November 1). Three Sabah detention centres to come under EMCO on Tue. New Straits Times. Retrieved from https://www.nst.com. my/news/nation/2020/11/637133/three-sabah-detention-centres-comeunder-emco-tue

Nadesan, M. H. (2008). Governmentality, Biopower, and Everyday Life. New York: Routledge.

Nah, A. (2012). Globalisation, sovereignty and immigration control: The hierarchy of rights for migrant workers in Malaysia. Asian Journal of Social Science, 40(4): 486-508. https://doi.org/10.1163/1568531412341244.

Nortajuddin, A. (2020, June 2). Malaysia's immigration depots: COVID-19 hotspots. The ASEAN Post. Retrieved from https://theaseanpost.com/ article/malaysias-immigration-depots-covid-19-hotspots

Ong, A. (1995). Making the biopolitical subject: Cambodian immigrants, refugee medicine and cultural citizenship in California. Social Science \& Medicine, 40(9): 1243-1257. https://doi.org/10.1016/02779536(94)00230-Q.

PATI Filipina terkandas akibat PKP mula diusir hari ini (2020, July 3). Sabah Post. Retrieved from https://www.sabahpost.net/2020/07/03/pati-filipinaterkandas-akibat-pkp-mula-diusir-hari-ini/

Radhi, N.A.M. (2020, June 6). Illegal immigrants free of Covid-19 to be deported starting today. New Straits Times. Retrieved from https://www. nst.com.my/news/nation/2020/06/598481/illegal-immigrants-free-covid19-be-deported-starting-today

Ravindran, A. (2020, October 23). It's everywhere: Sabah, ground zero of Malaysia's Covid-19 epidemic. Codeblue. Retrieved from https:// codeblue.galencentre.org/2020/10/23/its-everywhere-sabah-ground-zeroof-malaysia-covid19-epidemic/

Razak, A. (2020, May 21). UNHCR urged to develop mechanism to assist detained refugees, asylum seekers. New Straits Times. Retrieved from https://www.nst.com.my/news/nation/2020/05/594360/unhcr-urgeddevelop-mechanism-assist-detained-refugees-asylum-seekers

Rodzi, N. (2020, April 30). Once embraced by Malaysians, Rohingya now 
fear attacks with a rise in xenophobia. The Straits Times. Retrieved from https://www.straitstimes.com/asia/se-asia/once-embraced-by-malaysiansrohingya-now-fear-attacks-with-a-rise-in-xenophobia

Rose, N. (1999). Medicine, history and the present. In C. Jones \& R. Porter (Eds.), Reassessing Foucault: Power, Medicine and the Body (pp. 48-71). London: Routledge.

Rosen, G. (1993). A History of Public Health. Baltimore: Johns Hopkins. Roth, K. (2020, April 3). How authoritarians are exploiting the COVID-19 crisis to grab power. Human Rights Watch. Retrieved from https://www. hrw.org/news/2020/04/03/how-authoritarians-are-exploiting-covid-19crisis-grab-power

Salter, M. (2006) The global visa regime and the political technologies of the international self: Borders, bodies, biopolitics. Alternatives, 31(2): 167-89. https://doi.org/10.1177/030437540603100203.

Sandanasamy, F., Paavilainen, M., \& Baruah, N. (2020, May 8). International Labour Organization Regional Office for Asia and Pacific Working Paper, The COVID-19: Impact on migrant workers and country response in Malaysia. Retrieved from http://www.oit.org/wcmsp5/groups/public/--asia/---ro-bangkok/documents/briefingnote/wcms_741512.pdf

Somiah, V., Usman, M.R., \& Baltazar, A. (2020, March 22) Remembering Sabah's undocumented in a panicked Malaysia. Malay Mail. Retrieved from https://www.malaymail.com/news/what-you-think/2020/03/22/ remembering-sabahs-undocumented-in-a-panicked-malaysia-vila-somiahmichelle/ 1848908

Stahl, C. (2001). The impacts of structural change on APEC labor markets and their implications for international labor migration. Asia and Pacific Migration Review, 10(2-3): 349-377. https://doi. org/10.1177/011719680101000302.

Sukumaran, T., \& Jaipragas, B. (2020, May 1). Coronavirus: hundreds migrant workers arrested as Malaysia cracks down on migrants in COVID-19 red zones. South China Morning Post. Retrieved from https:/www.scmp.com/week-asia/politics/article/3082529/coronavirushundreds-arrested-malaysia-cracks-down-migrants

SUARAM. (2006). Malaysia, Human Rights Report 2006: Civil and Political Rights. Petaling Jaya: Suaram.

SUHAKAM. (2020). Press statement No. 15 of 2020: Suhakam urges authorities to cease arrest of undocumented migrants during Covid-19 
Crisis. Retrieved from https://www.suhakam.org.my/press-statement-no15-of-2020-suhakam-urges-authorities-to-cease-arrest-of-undocumentedmigrants-during-covid-19-crisis/

Thailand job loses may hit 10 million if virus outbreak drags on (2020, April 13). Reuters. Retrieved from https://www.reuters.com/article/us-healhcoronavirus-thailand-jobs/thailand-job-losses-may-hit-10-million-ifvirus-outbreak-drags-on-idUSKCN21V0LV\#

UNHCR Malaysia. (2020). Figures at a glance in Malaysia. Retrieved from https:/www.unhcr.org/en-my/figures-at-a-glance-in-malaysia.html

___ (2021) Figures at a glance in Malaysia. Retrieved from https://www.unhcr.org/en-my/figures-at-a-glance-in-malaysia. $\mathrm{html}$ ?query=rohingya $\% 20 \mathrm{in} \% 20$ malaysia

Vertovec, S. (2007). Super-diversity and its implications. Ethnic and Racial Studies, 30(6): 1024-54. https://doi.org/10.1080/01419870701599465.

Wahab, A. (2020). The outbreak of Covid-19 in Malaysia: Pushing migrant workers at the margin. Social Sciences \& Humanities Open, 2(1): 100073. https://doi.org/10.1016/j.ssaho.2020.100073.

Welsh, B. (2020). The Covid-19 factor in Sabah polls. Retrieved from https:// bridgetwelsh.com/uncategorized/the-covid-19-factor-in-sabah-polls/

Whither ASEAN unity (2020, April 14). The Jakarta Post. Retrieved from https://www.thejakartapost.com/academia/2020/04/14/whither-aseanunity.html

Wiertz, T. (2020). Biopolitics of migration: An assemblage approach. Environment and Planning C, Politics and Space. https://doi. org/10.1177/2399654420941854.

Yusof, A. (2020, March 30). COVID-19: Malaysia to implement enhanced measures for second phase of movement control order. Channel News Asia. Retrieved from https://www.channelnewsasia.com/news/asia/covid19-malaysia-to-implement-enhanced-measures-for-second-12589280

Zolkepli, F. (2020, April 8). 6000 near Masjid, India affected after 15 new cases found there, The Star. Retrieved from https://www.thestar.com. my/news/nation/2020/04/08/6000-near-masjid-india-affected-after-15new-cases-found-there 